\title{
Ottoman Empire at the Dynamic Game of European Powers in the 15th Century and Early 16th Century
}

\author{
Elton Demollari \\ University of Tirana, Tirana, Albania
}

\begin{abstract}
World history consists of many important stages and phases that we have left deep traces. One of them is the history of the Ottoman Empire. Indeed, its history is too complicated. It includes not only the history of the Ottoman dynasty, but also the stories of many people who either Ottoman Empire had conquered or administered by it. This story has to do with connections and relations with neighbor Ottomans in Europe and Asia and has to do with wars and battles between Ottoman and European empires. It also includes games and centuries' diplomatic conflicts between Ottomans and Europeans. Historians have written the concise history of the Ottoman Empire under the European perspective, according to European judgments and prejudices. But the author will try to write the history of the Ottoman Empire under the dynamics of the European powers in the 15th and 16th century, especially the causes and reasons, which can adjust their vein of truth and reality.
\end{abstract}

Keywords: Ottoman Empire, Sultan Mehmed II, Christianity, Turkish wars, jihad

The Ottoman Empire was a giant country between Europe and Persia and included the Balkans, Turkey, and the Arab area including the holy places-Mecca and Medina. Empire was created by nomadic tribes, who came after the arrival of the Mongols from Turkmenistan and eventually settled in Asia Minor. The godfather of Osman of the early 14th century was the ruler of the Clan Kynyk who had descent Turkmen and Muslim belonged faith. In 1299, Osman II or Genç Osman (Osman the Young) declared independence for the Beylik (kingdom) of his Rum-Seljuk Empire. Therefore, people traditionally take this year as the year of the founding of the Ottoman Empire. Year after year, first Osman took its dominance over other Turkish tribes and expanded its area of rule even at the expense of the Byzantine Empire. In the 14th and 15th century in the Ottoman Empire, it began a period in world history which is known as the "boom period". By the mid-14th century, Europe began to feel threatened by the Ottoman Empire, compared with other kingdoms and countries, such as Russia, Austria, Spain, Venice, Poland, etc. Ottomans had taken an unprecedented development. These countries were its largest enemies in the world. The author is emphasizing level of immensely rule development by establishing and exercising its power and hegemony everywhere. By 1451, the Ottomans had their sevenfold hegemonic space and turned into a scary superpower. It became a determining risk and threat to these countries and other European kingdoms. It is because the Europeans do not see the strength and expansion of the Ottomans with good eyes. In their opinion, the Ottoman Empire could endanger all of their area of influence, which had been created with the blood forever. One of the most important reasons that the Ottoman Empire

Corresponding author: Elton Demollari, Ph.D. candidate, researcher, Department of History and Philology, University of Tirana, Albania; research fields: history and international relations. E-mail: eldemollari@yahoo.com. 
took a rapid development between 1400 and 1600, which reached its "boom period" is the Ottoman army. It may frighten all European armies. The Ottoman Empire was a direct clash with the major European powers in their victory over Kosovo Polje on June 28, 1389, and especially after the bloody battle of Nicopolis and Mohaçës in Hungary in 1526. This caused a great panic among the European superpowers. The largest empire opponents in this period were Austria, Spain, Venedigu, the Vatican, Poland, etc. What goals and purposes Ottoman Empire aims to achieve in the West, it is more like mind to understand. As did Alexander the Great by invading the East, this order was also Sultan Mehmet II (Mehmet the Conqueror) to attack and occupy the West. West and the occupation are all desire and purpose of Mehmed II. He wanted to be able to spread his authority in Rome by putting victorious half moon over Christian churches at least. Encouraging call for all imperial troops was "Rome! Rome". With the name of the Sacred City, they wanted to give them wings and force to their troops, because their main priority was the invasion of the Papal throne. This would be the culmination of Sultan career. "Red Apples" (Kizil Elma) to contemporaries was the Sultan of the Holy City. Venedigu was queen of maritime trade in the Mediterranean and it is not like the Ottoman Empire at all. Therefore, between the two superpowers countries developed many bloody battles. On April 18, 1454, Mehmet the Conqueror (Mehmet Fatih) signed a treaty with Venedigut Senate (Signoria), as well as an agreement under which shall assure traders of both directions of freedom trade at the partner countries. Bartolomeo Marcello, Venetian ambassador in Istanbul, led the negotiations and on behalf of the Signoria, he apologized to the Sultan for public participation in the protection of the Venetian troops of Constantinople, as well as the silence of killing citizens and especially Venetian Bailos (messenger) Girolamo Minotte by Ottoman. This once again demonstrated the strength and the power and supremacy of this superpower, which was able to do everything. Even Sultan Mehmet II once said: "In the world, there should be only one empire, one faith, and one hegemony".

In these few words, it sums up all intents and purposes annexation of Sultan Mehmed the Conqueror, to put under his heel throughout the West. And it coincided with the situation, which was passing Europe itself. The situation in Italy was rather chaotic, dominated by the rift between the Italian states. The Sultan knew it very well because his envoys informed him in detail about everything, which happen in these countries. This disruption is reflected especially in the relationship among Venice, Milan, and Florence.

Duchy of Milan had an extreme hatred toward Venice and she took advantage of the plight of the republic - to intervene in the island region of Brescia. When Venice suffered heavy losses in the battle of Levantos, the envoy of the Duke of Milan, Nicodemo Tranchedini, in July 1453 in Florence said: "I wish that Venice suffer as badly, but not to the point, how to say, the loss of the Christian faith and I do not doubt that you share the same view".

But was it a bitter truth? From this came to the doubts, the Christian faith was losing ground to Islam. And this very thing feared European superpowers. Although, European countries argue about stupid things, the author still thinks that at some point, they were of one mind, which is hatred against Turks.

\section{Turkish Wars, Wars Against Christianity}

"The enemy is in front of our door. If we were not given the help of the Lord, then ax will fall on our roots and it means, happened in the name of Christ".

Gaza (Jihad, Cihad) or jihad, Holy War, was the ideal, and one of the most important factors of the founding of the Ottoman Empire. The purpose of the Holy War was not the disappearance of the world of 
"infidels", but their surrender. If we look at the map of the Ottoman Empire during this period, we will notice that it became a real danger for the whole of Europe.

This is seen in the correspondence between Pope Pius II and the last Bishop of Semedrias, Stjepan Tomasevic, in which highlighted urgently in order to take consider against real threats of the Ottoman Empire to Christianity. It is felt in the words of the king of Denmark and Norway, Christian, who compares the Turks with Monster Apocalypse, which comes from the sea bed. He himself expressed the desire to participate in the war against this monster. Meanwhile, Pope of Rome made a call to organize a crusade against the Ottoman Empire, but none of European rulers expressed readiness to participate in this crusade. This fell on deaf ears. Why did this happen?

(1) England had problems with her state unification;

(2) For King Karl VII of France, the most important was continuation of the war against England, rather than east enemy-Ottoman Empire.

Therefore, we must not forget the hostility century between England and France. Here let us remember the 100-year war between these countries. Pope Nicholas V was felt rather disappointed by events happened around.

Papal Legation efforts were in vain to achieve unification between European superpowers, and to organize a general crusade against the Ottomans.

Here is what is written in the letter addressed to Bishop Enea Silvio Piccolimin Pope Nicholas V on July 12, 1453:

Now Mehmet the Conqueror rules over us, he rolls Turkish sword over our heads. The Black Sea is closed for us, Wallachia is under the power of the Turks. From there will raid Turks in Hungary and Germany. Undering their rule will prevail disunity and enmity. The kings of France and England have raised arms against each other. Only Spain is enjoying a certain tranquility and Italy could find inner peace again struggling against anyone. How much better it would be, that our troops, our weapons turn them against the enemies of our faith. I do not know if this is your secret desire that hides in your heart, Grace, Holy Father!

In these words, there is a great fear of Europeans toward the Ottomans and also a desire of a European, a cleric to dispatch them from Europe. But to other side came out as an immediate task of uniting all European powers against Ottoman Monster. And Pope Nicholas V, deeply touched by these words, released an advertisement two months later, where Sultan Mehmet the Conqueror portrayed as a forerunner of the antichrist, and compared him with the red dragon of Revelation of the Apostle John to the seven Diadema (crowns) and ten horns. But even this not availed to princes and kings of Europe, consequence of this was their total indifference. Even his successor, Pope Pius II, planned and designed a Holy War against Ottoman Empire. Furthermore, this and his goals he presented on September 23, 1463, in a secret Konsistorium before all College of Cardinals. Therefore, the Pope and Venice seemed tied an alliance with the Burgundy, under which parties to a three-year period will provide each other mutual aid and mutual promise of peace. Before this fact, European princes and kings were still undecided and drawn. In this difficult situation in November 1463, Pope Pius II claimed in a conversation with a European representative:

Given the indifference and negligence of European rulers, forced to take command of the crusade alone. If the Turks advancing forward as until now, then in a short time all will find ourselves under Ottoman choice. What is in my hand, I will do it. God help me! 
But because of the death of Pope Pius II, all efforts for a common European crusade were faded and left in limbo. During this time, the Ottoman Empire had extended its land hegemony. Although Venice was helped by unusual European superpowers (Spain, France, the Holy See, etc.), it always failed to face the Ottoman Empire. Ottoman strength and power proved too hard to order Saint John, which the Turks were expelled from Rhodes Island in 1522. This order controls maritime trade in the Eastern Mediterranean. Ottomans managed to impose their hegemony and control over the entire Eastern Mediterranean after the invasion of the island of Rhodes. But the primary purpose of Ottoman was occupation of Vienna, the Habsburg capital city. During this time, there took place many bloody battles between the Ottomans and the European powers, which ended in total failure of the Ottomans, because the European powers were united as never before. But one of the most glorious periods and longer Ottoman Empire, which culminated in and had the most rapid development, was Suleiman I governance, follower of Selim I. He had a huge impact, not only on Ottoman history, but also on European and Western, he was called "the Magnificent" by the Europeans. He turned to one of the main actors in the divergence between European powers. Sulejman I also pursued plans of his father Selim I-the universal nature of the Ottoman Empire. He wanted to have his own under his heel of Europe and so he prepares for a penal expedition. In a few years, he spread his influence across Europe. But the question arises: Why did all this happen? What were the reasons?

The first reason was the deep rift between European superpowers. Here we can mention that the 100 years war between England and France, this brought the total defeat of both countries and the decline of their influence in the international arena. Either case when the leaders of the Order of Saint John's material and military assistance requested by the European powers to Rhodes recovering from the Ottoman Empire and they could not receive this assistance.

The second reason was the extraordinary growth of the Ottoman military power. The Ottomans had a very large and strong army, which Western Europe in this period does not even lead in mind. Ottoman soldiers had an iron discipline and a great fighting experience, which are not owned by European soldiers.

But later events would receive a stream next. Christian European powers led by Spain reached their first win against the Ottoman Empire at the battle of Lepantos on October 7, 1571. Collision impacts Lepantos Osman to bring cleansing in the Mediterranean Sea and the breaking of strong Ottoman naval fleet.

So, in the author's view and the facts mentioned above, stand in conclusion, the Turkish wars were not only of a military character to rule the whole world, but they were religious to install in any location and strength of their faith. One example is the case of Albania, where many Albanians were forced to change their faith.

\section{Ottoman Diplomacy and Europe}

Poland at this time was a great power and a powerful kingdom. It has been one of the oldest states, which has diplomatic relations with the Ottoman Empire too early. But after the death of the last king of Poland, Jagiellon dynasty fell to turbulence and upset because of the election of the king. The Ottomans wanted a king of their choice. There has been a great correspondence between Poland and the Sublime Porte. Why did all this happen?

(1) First, Poland cannot be ruled by a foreign king, in that case, such risks will not be missing. For Ottoman policy better would be a local king, who knew the internal problems very well and also Ottoman interests in Polish conditions, rather than a foreign king, who will wield in favor of its origin country. If it were a king disliked by Sublime Porte, then it will be threatened by war; 
(2) Second, in the case of the election of the king of the dynasty of Piasten, internal and unrest rivalry among Poles will still continue.

Even a candidate of Poland's neighboring countries (Sweden, Russia, and Austria) would treat the Ottoman Empire as a direct enemy. Even these countries were interested in this issue, thus, they began a hectic diplomatic activity in European royal yards. All countries tried to put their influence using their mechanisms. Habsburg dynasty wanted to further expand its influence in Poland. And so in this way, it would be a direct threat to Hungary Reman again. But everything failed at the outset, because the risk for Poland to be involved in conflict, Osman was too big and the second Poland will lose all its traditional freedoms. Here suddenly entered into talks and France. Why? Combining with the French was the cornerstone in Ottoman politics and diplomacy in Europe. On one hand, the French kings were known to the world as ardent defender of the Christian faith against the infidels. They dream to become lords of the West, to expel the infidels, to liberate Constantinople, and to obtain from the Turks and Greeks holy cities. But on the other hand, the French was the only superpower of European Christendom, which had relatively good relations with the Ottoman Empire and had built them pragmatist basis. So they were the natural allies of the Ottomans.

On the other hand, Martin Luther initially held a passive attitude toward the Ottoman Empire, because Lutherans thought, the Osman devil was seen as a punishment from God against the world. Sultan hoped in cooperation with Lutherans. The Sultan asked them to continue cooperation with the French and the fight against the Pope.

So the sultan wanted to use the protection and support of the Lutheran and Calvin as a springboard for European policy. French Calvinists thought that alliances should be directed against the Ottomans Catholic Spain. So these collaborations and support would base their policy on Europe. Friendly relations would receive a big raise after the defeat of Lepantos (October 7, 1571). Clashes between Spain and France, as well as between the Habsburgs and the Sublime Porte would deteriorate further. Therefore, this approach was too French for Osman necessary. France used the defeat to rebuild its area of influence, which for the sake of reality was too low. The French also won privileges of religious, political, and trade at the expense of the Ottomans. Thus, relations between France and the Ottoman Empire became narrower. Why all this?

Franz I was not selected as the Christian God, even though he had signed a concordat with the Pope of Rome in Bologna, to lead a crusade against the Ottomans. He gave up. But despite of the traditional friendly relations, between the two countries started cold time relations when the French influence like meddling with the election of a candidate to the French throne of the Empire a neighboring country. Sultan did not like that. He did not see with good eye because France wanted to unite Moldavia and Wallachia with the Polish crown and desired to be tutor of Poland. It wanted to intervene in the selection of the king in Poland. But this thing, Ottoman Empire could not allow itself without taking in consider its position in European political scene. So Porte had to make a calculated diplomatic game very well. It rejected the French proposal. Signing excellent cooperation between the Ottomans and the French was the moment, when Hungarian Fragipani as French envoy to Constantinople, he made Solomon II to attack Hungary, while Franz I wanted to interfere in Spain. This was an important historical fact which was rather extraordinary. But in this period, the Ottoman Empire began the decline and degradation. It lost its splendor and glory. In the end, she surrendered completely. Ended up with "Honey Years” for gigantic Ottoman Empire, "Sic Transit Gloria beat!". 


\section{Conclusions}

Ottoman Empire in the dynamic game of European powers in the 15th century and early 16th century had a very high and unheard level of development for the era. This was not seen with good eyes by European. It had a huge impact on world history and on the most important European events. It was first violin for this period. Ottoman diplomacy was one of the most important weapons in the conquest of the world. But as often said, there are two sides of the medal. One, just mentioned, and the other was the decline, westerly. So, it brought the loss of its influence in the world, it also resulted in a change in the role of the European powers in the international arena. On one hand, the goal of Ottoman policy was political disunity in Europe, the weakening of Habsburg but on the other hand was even obstructing the organization of European crusades against it.

\section{References}

Austro-Turcica 1541-1552. (2007). Diplomatic files of the Habsburg embassy dealings with the Sublime Porte in the time of Suleyman the Prachtigen. Austria: Austrian Academy of Sciences Press.

Babinger, F. (1953). Mehmed der Eroberer und seine Zeit. Weltenstürmer einer Zeitwende (Mehmed the Conqueror and his time. World striker of a new era). Munchen: Verlag F. Bruckmann.

Babinger, F. (1959). Mehmed der Eroberer und seine Zeit Weltensturmer einer Zeitwende (Mehmed the Conqueror and his time. World striker of a new era). Munchen: Verlag F. Bruckmann.

Beydilli, K. (1976). Die polnischen Konigswahlen und Interregnen von 1572 und 1576 im Lichte Osmanischer Archvalien (The Polish king elections and interregnum of 1572 and 1576 in the light of the Ottoman archives). Munchen: Verlag DR. Dr. Rudolph Trofenik.

Creasy, E. S. (1854). History of the Ottoman Turks. London: R. Bently.

Galletti, J. G. A. (1801). Geschichte des turkischen Reiches (The history of the Ottoman Empire). Gotha: Perthes.

Göllner, K. (1968). Opinion publik mbi luftën turke ne gjysmen e pare te shekullit XVI Tirana (The public opinion about the Turkish war in the first half of the XVI century Tirana).

Hegyi, K., \& Zimanyi, V. (1989). The Ottoman Empire in Europe. Budapest: Verlag Corvino.

Hertzberg, G. F. (1883). Geschichte der Byzantiner und des Osmanischen Reiches bis gegen Ende des XVI Jahrhunderts (The history of the Byzantine and the Ottoman Empire until the end of the XVI century). Berlin: G. Grothesche Verlagsbuchhandlung.

Inalcik, H. (1994). The Ottoman Empire: The classical age 1300-1600. London: Phoenix.

Inalxhik, H. (1997). Perandoria Osmane-Periudha klasike 1300-1600 (The Ottoman Empire: The classical age 1300-1600). Skopje.

Jorgo, N. (1908). Geschichte des Osmanischen Reiches. Nach den Quellen dargestellt (History of the Ottoman Empire, presented according to the sources). Gotha: Friedrich Andreas Perthes Aktiengesellschaft.

Koehler, K. (1907). Die orientalische Politik Ludwigs XIV (The oriental policy of Louis XIV). Leipzig: Universität Leipzig.

Newman, J. H. (1854). Die Türken in ihren geschichtlichen Beziehungen zur Christenheit (The Turks in their historical relationships to Christianity). Köln: Verlag von J.P. Bachem.

Seiz, J. C. (1854). Die Turken, eine Krieger-Nation, wie sie entstanden, ein grosses Reich in drei Welttheilen durch Gewalt der Waffen gegrundet und bis auf unsere Zeit tapfer behauptet haben (The Turks, a warrior nation: How they created a great empire, who have three parts of the world founded by force of arms, claiming bravely down to our time). Pest: Verlag von Gustav Heckenast.

Shaw, S. J. (1976). History of the Ottoman Empire and modern Turkey, empire of the Gaziz. The rise and decline of the Ottoman Empire (Vol. 1, pp. 1280-1808). London: Cambridge University Press.

Von Besse, A. (1854). Das türkische Reich (The Turkish Empire). Leipzig: Gustav Kemmelmann.

Von Hammer, J. (1834). Die Geschichte des osmanischen Reiches (The history of the Ottoman Empire). Gotha: Perthes. 